\title{
THE UNDISCLOSED FRONT - ASPECTS OF STRUCTURAL PATTERN AND ACTION NETWORKS OF SUBVERSIVE-RECONAISSANCE ACTIVITIES IN CONTEMPORARY CONFLICT AREAS. OPEN SOURCES ANALYSIS
}

\author{
Arnold Warchal \\ Wojskowa Akademia Techniczna \\ Przemysław Żukowski ${ }^{1}$
}

\begin{abstract}
Topics considered in the area of special intelligence activities can be oriented towards the many levels of state's security interests. When it comes to security strategy, the data acquired by an open source intelligence in addition to other sources converts into very important knowledge, sometimes vital and often instrumental for protection of state's sovereignty. Information on subversive agenda of an aggressor is always hard to come by, but an open source analysis can be somewhat helpful in tracing possible goals, extent and capacity of foreign secret agenda to destabilize a country or a region. Recently we have an example of such activities, when we observe the Russian sponsored war effort in eastern Ukraine, and its Crimean peninsula annexation by subversive forces. Analyzing the information gathered in reference to Russian actions in Ukraine and its other neighbors, including especially Poland, we can observe specific pattern leading to control of important aspects of state's security. Authors in the following article review available facts and data connected to intelligence subversion modes and activity patterns that may lead, as is exemplified by the case of Ukrainian conflict, to final gain in political or military goals.

Keywords: Intelligence, counterintelligence, covert operations, overt operations, subversion, politics.
\end{abstract}

\section{Introduction}

The Russian Federation launched its operation destabilizing Ukraine on the night of 27/28 February 2014. The main goal was to take full control of the Crimean peninsula. The results of the fighting that took place in the eastern part of Ukraine at that time was easy to predict. The Russian separatist movement slowly unveiled and then fully revealed the weakness in national security of Poland's neighbor, and Ukraine's lack of preparation to stand up against the aggressor. The essential pillar of Russia's activity in the region was clandestine prior to final outcome, and was based on diversionary actions. This became fully obvious after the loss of the Crimean peninsula by the Ukraine.

The Russian operation began on the peninsula with unidentified to this day armed groups that took over the main offices and other important State institutions

1 Ph.D. candidate at the MUT Cybernetics Faculty / Doktorant WCY WAT. 
in that part of Ukraine. Their actions caused the paralysis of State administration and self-government in the occupied towns, leading to the announcement on March $11^{\text {th }}$, on the Crimean autonomy, and paving the ground for the plebiscite on March $16^{\text {th }}$, which resulted in the outward annexation of the Crimea by Russia.

The military situation and results of fighting in Ukraine, in its early stages did not affect the view of NATO countries on ephemeral status of Crimea. Hence, Ukraine's situation became hopeless. The country due to its weak military potential, and being unable to identify the enemy, was not able to engage in direct combat with the aggressor. In order to maintain its status quo in international arena it had to adopt conflict rules imposed by the Russian Federation. It had to cope with information forwarded to international public opinion and act responsively within the international politics' interests, often against its own interests. Therefore, Russia has achieved its goals in this conflict already in February of 2014. It was able to impose its strong point of view using a disinformation techniques, fully influencing the conflict's schemes of actions.

The Russo - Ukrainian antagonism from the first half of 2014, became for many of the war researchers, an excellent analysis model for special operations proceedings and a determinant in definition of, then not a common type of conflict, known as the "hybrid war". The theory of hybrid war assumes the use of custom and varied war techniques applied to subjugate a country. Implementation of those can be done by different means of political, economic and military information and disinformation. It is a type of action where war is not an apparent military undertaking but a military force may be used as a notion of threat in conjunction with non-military main agenda. This type war does not lead to a destruction of the nation's human potential, yet it is as dangerous as any, since it can lead to nation's subordination to the external influence and consequently may imply the loss of independence ${ }^{2}$.

However, during the Crimean operations we do not notice any new type of special forces skills being used. The aggressor aiming first at the public opinion using a combination of known operational skills, rested on NATO's military staff and security analysts' unwillingness to predict potential capacity of such activities. At that moment already a notion of failure was built up, hence calling this operation a "hybrid war" was rather an excuse or overstatement. The excuse resulted from the sluggishness of NATO's analysts realizing, after destabilization of its buffer country through initiative given away to Russians became a fact, the need for explanation. We must understand in such a case that "the hybrid war" is not really a new finding, it cannot be labeled a new form of political allowance prior to war, since some of its traits and aspects were already described in VI c. BCE by Sun $\mathrm{Tzu}^{3}$ in China, and in

\footnotetext{
2 Hybrydowa wojna - hybrydowa reakcja, http://www.nato.int/docu/review/2014/Russia-UkraineNato-crisis/Russia-Ukraine-crisis-war/PL/index.htm (dostęp: 29.12.2015 r.)

3 Sun Tzu, Sztuka wojny. Traktaty, Gliwice 2004.
} 
The undisclosed front - aspects of structural pattern and action...

III c. BCE India in the political treaties titled Arthashastra ${ }^{4}$ by Kautilya, where entire chapters were devoted to the subjects of war, spying and "special forces" activities in a field of subversion. Since those times subversion has been hidden under many masks, both in military and political provenience, and no doubt its definitions must be kept up to date for intelligence and counterintelligence purposes 5 .

Nonetheless, what became apparent during the Crimean operation was a large scale subversion used in the Ukraine to discredit it and divide it as a nation. Perhaps it shouldn't be a surprise considering large Russian ethnic population in Ukraine, especially in its eastern and southeastern part. It is believed that in different subversive activities, that included also deception, special forces were used and were supported by the groups ideologically committed to Russia. Within those groups there were both the regulars of the Russian special forces and mercenaries, as well as other human resources associated with the organized crime, non-governmental organizations, and other friendlies, or simply ethnic Russians.

For the purpose of this article such groups can be defined as Subversive Reconnaissance Groups (SuRG). As a phenomenon of conflict arena it is a fusion of the old and new technics of political and military ways - where special operations activities has been evolving in consideration of fluctuations in political, economic, military and the other changes of a global strategies in domination games. Its wide spread across different spheres and levels of aggressor's field of interest has grown into a net of quantifiable quality, and quiet recently has been observed on number of occasions in its spread throughout the Eastern-European theater. Understood that the changing environment of intelligence and special operations' activities requires a new, more diverse and wide-ranging method of analysis, the SuRG's activities do not have to be, and usually are not on the outset military in scope, since its specific role is to influence and prepare for final political or military solution ${ }^{6}$.

\section{OSINT7 analysis of subversion}

It is possible to describe activities of the SuRG based on the official information sources (reports, press articles, eyewitness account and historical material) with a proper analysis attempt of its structures and characteristics. The aim of the authors in such descriptive analysis is to uncover grid patterns of overt and covert operations

4 Kautilya, Arthashastra, http://www.lib.cmb.ac.lk/wp-content/ uploads/2014/01/ Arthashastra_ of_Chanakya_-_English

5 See: W. Rosenau, Subversion and Insurgency, Rand Counterinsurgency Study, Paper 2, Occasional Paper Prepared for the Office of the Secretary of Defense, http://www.rand.org/content/dam/rand/ pubs/occasional_papers/2007/RAND_OP172.pdf

6 See, for example: W.J. Lahneman, The Need for a New Intelligence Paradigm, "International Journal of Intelligence and CounterIntelligence" 2010, http://dx.doi.org/10.1080/08850600903565589

7 OSINT - open source intelligence. 
of those groups in the contemporary conflict area. In such a case, particular focus can be directed towards the destabilizing activities of SuRGs in Estonia, Georgia and Ukraine in the $21^{\text {st }}$ century.

Such an approach rests of course also on conceptualization of a problem following the past activities observed, in such a case nothing can replace different intelligence resources available. Hence, the authors assume that open source intelligence at least allows to notice the basic pattern of such activities analyzed in a given research. The authors also take into account possibility of potential actions of said groups in Poland during a regional conflict, coincidental events or other attempts to destabilize internal and external security of a state.

Subversive operations are irregular and unconventional acts of pressure aimed to create harmful effects on the enemy. Their particular significance and identity rest on fact that they are carried clandestinely in the territory of a victim state. The main aim of such activity can be manifold 8 :

- the acquisition of detailed information;

- the incapacitation of important objects;

- derangement of the basic activities of the State structures (government, police, army);

- planned psychological brunt on the civilian population;

- organizing and supporting the separatist activities.

While finalizing an act of subversion and preparing grounds for an occupation, a series of unique operations are conducted, by groups designated for a given purpose, organized with particular training and equipment, and specialized units using tactics and operational techniques surpassing the standards adopted by the conventional armed forces ${ }^{9}$. Specific objectives of subversion require some offensive clandestine activities usually carried out in a politically sensitive environment, in order to achieve planned military, economic, or information gathering goals ${ }^{10}$. It can be estimated that, in the context of subversion special forces will perform at least three main tasks ${ }^{11}$ :

- intelligence, and target intelligence ${ }^{12}$ - characterized by activity of information gathering, a special reconnaissance with a high degree of reliability on field of action, risks, objectives and assessment of the effects of existing measure;

8 Działania specjalne, Sygn. Szt. Gen. 1221/85, Warszawa 1985, s. 14.

9 Doktryna Operacje specjalne DD/3.5, Dowództwo Wojsk Specjalnych, DWSpec. 1/2011, Kraków 2011.

10 Special operations "Military activities conducted by specially designated, organized, trained and equipped forces using operational techniques and modes of employment not standard to conventional forces..." (see full definition at: AAP-6 NATO Glossary of Terms and Definitions, p. 325).

${ }_{11}$ Doktryna Operacje specjalne DD/3.5, Dowództwo Wojsk Specjalnych, DWSpec. 1/2011, Kraków 2011

12 AAP-6 target intelligence defines as: „Intelligence which portrays and locates the components of a target or target complex and indicates its vulnerability and relative importance", op. cit., p. 347. 
The undisclosed front - aspects of structural pattern and action...

- direct action ${ }^{13}$ - implying kinetic „small scale offensive” against the objectives of major importance, strategic and tactical;

- military support - namely the activities and effort to support of friendly units, including training, material and technical support and use of local forces in combat operations.

In reference to historical material describing organizing of subversions by the Russian KGB, upon analyzing it we can notice a scale and scope of induced information on a subject. Subversion department was the most clandestine division of KGB intelligence. As an operational unit it was active under a name of division "W" or division "S" 14 . Its activity focused mainly on ${ }^{15}$.

- development of subversion and sabotage plans against the strategic facilities of the military, industrial, energy, transport and communication systems of potential hostile countries, in case of the armed conflict or other emergencies, coordinating its implementation and realization by its own reconnaissance-subversion personnel;

- planning and implementation of assassinations and acts of terror against the most active political activists, civil servants and intelligence officers;

- planning and implementation of secret kidnappings abroad;

- preparation, follow-up and monitoring in time of peace of the secret boxes with weapons for subversion-sabotage acts, in the event of conflict;

- enlistment of the support agents from amongst the local population (especially from those living alone, electricians, mechanics, locksmiths, pharmacists, doctors).

Based on the available open sources data we can notice an analogy between the KGB small subversion groups and the contemporary activities of subversion groups in the eastern regions of Ukraine, with subversion potential in other parts of Europe. Such an analogy is logical since it has been revealed by the Russian expert on the special operations, the GRU colonel Wladimir Kwaczkow, who together with other Russian specialists in 2010 identified the following types of activities with respect to the possible use of Russian reconnaissance-subversion groups: ${ }^{16}$

- special subversion acts, that is the activities carried out in order to cause most possible damage to the military, economic and informational potential of the enemy, destruction or disposal of key military facilities, command and

13 Direct action, "A short-duration strike or other small-scale offensive action by special operations forces or special operations-capable units to seize, destroy, capture, recover or inflict damage to achieve specific, welldefined and often time-sensitive results", p. 125, op. cit.

${ }^{14}$ L. Pawlikowicz, Aparat centralny 1. Zarządu Głównego KGB jako instrument realizacji globalnej polityki Kremla 1954-1991, Warszawa 2013, s. 232.

15 Ibidem, s. 233.

16 Ibidem. 
control systems, as well as misinformation, diversion of attention from the major goals planned;

- special intelligence-subversion acts, are the complex activities with purpose of gaining particular intelligence knowledge, that is the acquisition, processing and analysis of information using any means available including, observation at first but ranging through combat operations, capturing the chosen objects and people, and radio-informational and technical espionage. A crucial task of this form of intelligence is a deployment in the enemy territory of the irregular units and directing their activities towards creating a network of agents;

- special anti-terrorist activities, those are understood as the activities leading to identification, stopping and liquidation of subversion groups of the foreign armies, enemy irregular forces, terrorist organizations, as well as camps and training facilities on foreign territories. The scope of these operations also include cooperation with other security bodies in Russian Federation;

- covert psychological and informational activities, the whole variety of forms, methods, means and measures aimed at transformation of attitudes of the government, command and military personnel, and the civilian population of a country or its territory considered to be an enemy. The purpose of these activities is primarily a demoralization and confusion aimed at weakening of the resistance and leading to the desertions of soldiers. An important aspect of this kind of action is also causing the acceptance of the friendly attitude of the armed forces and the population towards the Russian troops, supporting opposition movements against to the authorities of the state or of its territory, and countering enemy propaganda;

- covert operations of organizing and carrying out the particular methods of armed fighting, relate primarily to organizing irregular units carrying out the tasks for the armed forces in name of vital interest of the Russian Federation. This includes the reconnaissance tasks for given entities, guerrillas, insurgent troops and groups, support and training for such groups. The organizations involved or potentially involved in conflict may become the objects for those practices;

- specific tasks, namely the humanitarian help for population living in the areas covered by military conflict;

- other tasks, those ordered by the power of the president of the Russian Federation or the Minister of Defense.

As we can notice from the above, one of the elements of subversion is a deception. It is an important one, if we consider that an example of a deception is misinformation aimed at the implementation of the foreign policy objectives of Kremlin, as per this case. We can conclude that once the policy objectives are controlled, the other acts 
The undisclosed front - aspects of structural pattern and action...

of subversion can be implemented, with a better chance of success. This is where the OSINT comes in handy. Sometimes when we check the information gathered, relating to possible activities of different personas, in the press or other media information systems, we can verify it with conjunctions to different types of data found in the open. The authors are aware that analysis of the open sources material should be done however with caution, but one should not throw away such an information without proper analysis, even if, as in this example case of the Russian Federation's activities, there may be used disinformation as the means for achieving specific goals. And this knowledge should also be counted in, as an negative element of a final equation.

Taking into account the main principles of conducting diversionary activities such as ${ }^{17}$ :

- the secrecy principle for all projects,

- the knowledge principle about the situation and forecasting of its development,

- the principle of aforethought and schematic activities,

- the avoidance principle of an open fight,

- the vigilance principle,

- the economy of force principle,

- the purposefulness of action principle.

Information obtained from OSINT without a doubt may organize a very large potential field of action. Subjected to conversion (analysis etc.) on the basis of accumulated knowledge can show many aspects of the investigation activities of the researched entity. The only prerequisite is its possibility of occurrence of a potential goal. Once in a while its sources are the politicians and the executives, or other giving perhaps not centralized but still important facts. One of the example of such facts is the analysis of the disclosures from an ex-officer of the Russian Federal Security Service (FSB) - the information on cooperation of the Russian agents with the radical islamic group - ISIS ${ }^{18}$. This information could be a proof of a wide scope or activities approved by the Kreml's policies, leading to a recognition that the political goal is more important for the Kreml, than means for achieving it. In the same interview, the officer also said that the riots in London in 2009, 2010 and 2011 were planned by the FSB and the SWR (Foreign Intelligence Service of the Russian Federation). By analyzing these relationships, you can see the links leading to the Russian Federation in terms, that its security services had all the possibilities to organize terrorist attacks in Paris in 2015, given that such an information can be verified also by other means ${ }^{19}$.

17 Działania specjalne, Sygn. Szt. Gen. 1221/85, Warszawa 1985, s. 15.

${ }^{18} \mathrm{Na}$ Ukrainie schwytali terrorystę z ISIS!, http://kresy24.pl/75360/na-ukrainie-schwytali-terrorystez-isis-byl-uzbrojony-po-zeby-foto/ (dostęp: 14.12.2015).

${ }^{19}$ Byly oficer FSB ujawnia. „Rosja zaangażowana $w$ rozruchy w Londynie, ataki w Paryżu, ISIS”. 


\section{Russian subversion in the Ukraine}

The Kreml's track of organizing and supporting subversive activities in the foreign territory is indicated by the information that the Ukrainian security forces (namely the SBU - the Security Service of Ukraine, and the antiterrorist brigade Alpha) gathered information and located in over twenty cities armed subversion groups active throughout Ukraine. In one of the raided apartments the security forces found a mighty arsenal of weapons like firearms and machine guns, approx. two thousand bullets, over forty grenades, $3 \mathrm{~kg}$. of TNT and 8 explosive devices prepared to be used in attacks by the sabotage groups. One of the net's member, a potential saboteur was an active sympathizer of the Ukrainian National Right movement. $\mathrm{He}$ was identified as Oleg Mużenko from Donieck, alias „Woodsman”20.

Additionally, on May 12th, 2015, close to city of Lugansk, the Ukrainian security service took captive of the cpt. Jewgienij Jerofiejew and sergeant Aleksandr Aleksandrov of the 3rd. Warsaw-Berlin Brygade of Special Operations. According to the testimony of the detainees they were flown to Ukraine with the task of conducting special intelligence operation ${ }^{21}$.

M. Wojnowski Nemtsov on the basis of the report indicates that, in the current phase of the conflict the Russian soldiers were the professional officers and other special services officers of Specnaz. It is also known that a private security agencies could have been providing up to $70 \%$ of the headcount of separatist's armed formations ${ }^{22}$. Ukrainian security services have identified some of them. Those identified, among the others, were ${ }^{23}$ Igor Girkin alias Srtielkov, possibly assigned in the FSB or GRU, or else in $45^{\text {th }}$ Detachement of Special Pupose Regiment of the Airborne Units of the Russian Armed Forces; Siergiej Zdanowicz, ex-instructor of Special Destination Center of the FSB.

It is evaluated that the subversion in the Ukraine was done by the assembly of highly motivated individuals. And is assumed therefore, that the subversion was enacted by the intelligence operatives, conscious about the goals and ready to make sacrifices, acting and controlled by some executive orders ${ }^{24}$. The group was most likely under the leadership of the subunits of special operatives from Spetznas ${ }^{25}$ and para-military orga-

20 The shoot out of the ukrainian SBU with the Russian agents in Kiev, http://kresy24.pl/75894/strzelanina-sbu-z-rosyjskimi-agentami-w-kijowie-sa-zabici-wideofoto/ (14.12.2015).

${ }^{21}$ Special intelligence operation - collection by any means necessary - from observation and tactical actions ranging from overtaking objects an persons, up to communications and radio intelligence including.

22 M. Wojnowski, Koncepcja wojny nowej generacji w ujęciu strategów Sztabu Generalnego Sił Zbrojnych Federacji Rosyjskiej, „Przegląd Bezpieczeństwa Wewnętrznego” nr 13 (17), Warszawa 2015, s. 33.

${ }^{23}$ Ibidem

24 T. Lewczak, ATO nie wojna, „PARABELLUM Niezależny Magazyn Strategiczny” nr 3/2015, s. 82.

${ }_{25} \mathrm{Jak}$ rosyjski specnazowiec-neonazista Krym od faszystów wyzwolit, strona internetowa: http:// kresy24.pl/69245/jak-rosyjski-specnazowiec-neonazista-krym-od-faszystow-wyzwolil-wideo-foto/, $(9.12 .2015)$ 
The undisclosed front - aspects of structural pattern and action...

nizations, among the others the Night Wolves. As it was presented by the Polish television station - TVP.INFO (its internet web page), the group of the Night Wolves was helping during the annexation of the Crimean peninsula by Russians. They were active in so called "self-defense" units and were helping in taking over the control of peninsula. In this subjugation, in activities of reconnaissance and subversion, there were also other groups active, the mercenaries ${ }^{26}$ mainly from Russia and Chechnya, plus the Cossacks.

The identified standard of volunteer and mercenaries recruitment for fighting on behalf of the separatist units shows that the main approach towards enlistments was done through social groups and organizations or veterans' associations ${ }^{27}$. Based on the sources, it can be established that recruited persons were preferably an average size single male with no families ${ }^{28}$. Non-governmental organizations led by the Kremlin officially did not take part in fighting and were directed towards the supply and support of the civilian population, but in reality their activities consisted providing the separatists with weapons and enlistees. The activity of above mentioned the Night Wolves is a good example of such actions. At the final moments of subversion they rode on their Harleys with Russian flags into Symferopol and Sevastepol right after the columns of tanks and trucks with so called the "green men"29.

The open source materials indicate that the Night Wolves were present at Crimea before the green men were observed. At the time of the referendum, which was supposed to legalize the previous subversion in the peninsula, in order to bond it with Russia, the members of the Wolves were seen active in terrorizing local population, especially the Ukrainians and the Tatars, but also those Russian who disliked president Putin's government. At an interview for the western press, the leader of the Night Wolves, Alexander Zołdostanov alias "Surgeon", openly lamented that many of his comrades have fallen in battles with, so called, Ukrainian "fascist". Clues as to ambiguity of expression by Surgeon can be found, according to the internet web page - wprost.pl, on the social networking site VKontaktie - the Russian equivalent of Facebook, and prove without the doubts with picture posts that the Night Wolves had its own subdivision fighting for the separatists. Based on the photographs and witness accounts ${ }^{30}$, it was discovered that this subdivision took part in regular fi-

26 T. Lewczak, ATO nie wojna, op. cit., s. 83.

${ }_{27}$ M. Wojnowski, Koncepcja wojny nowej generacji w ujęciu strategów Sztabu Generalnego Sił Zbrojnych Federacji Rosyjskiej, „Przegląd Bezpieczeństwa Wewnętrznego” nr 13 (17), Warszawa 2015, s. 33.

28 Physical selection of the candidates allows for masking of the units in operating environment for the urban actions, since people of the average growth and without characteristic traits do not stand out from the crowd. The lack of family prevents possible claims on the part of the next in kin, in the event of death.

${ }^{29}$ Nocne Wilki szczerza kły także na wschodniej Ukrainie, strona internetowa: http://www.tvp. info/19792456/nocne-wilki-szczerza-kly-takze-na-wschodniej-ukrainie (dostęp: 9.12.2015).

30 totewski Polak rosyjskich "Wilków” Putina, http://kresy24.pl/67504/lotewski-polak-rosyjskich-wilkow-putina/ (dostęp: 7.12.2015). 
ghting, for example in Lugansk. Its members were boasting that they fought at the front line, having its own weapons, own command and a banner with words The Night Wolves of Donbas ${ }^{31}$.

Using the open source intelligence we can underline the involvement of the "Wolves" stressing group's international connections as well as aggressive, both actively and potentially, dangerous activities. It is already proven since 2015, based on their activities in Ukraine, that the subversion is one of their goals. The structure of this big organization is very well developed. The foreign affiliates are accepted to this organization personally by chief of the major branch in Moscow, Alexandr Zaldostanov. Foreign membership of the Wolves is observed in FYRM, Serbia, Montenegro, Bosnia and Herzegovina, Bulgaria and Romania, among others. Its twin associations or related motorcycle clubs also exist in Switzerland and Germany.

This Zaldostanov's biker's gang, together with the International Alliance of Assault Forces is part of the "Wolf Holding of Security Structures". The Holding is directed by Gennady Nikulov, a senior military officer who was awarded, among the other medals, the "Russian Medal for Recovery of the Crimea"32. The company provides detective and other services: armed and unarmed protection of stationary objects, securing transportation of goods (in its own armored cars), installing of monitoring and tracking systems. On the site they also offer staff checks using the lie detector ${ }^{33}$. Attached to this "business" is holding's "Wolf International Centre for Special Training".

Looking at the holding's structure we can notice that the International Alliance of Assault Forces and the Night Wolves have autonomous arrangements but are directly run by Nikulov. This "business holding" have more than a dozen departments that range from, so called special purposes and security as well as finance or personal resources departments. The security department next to Moscow, has also its field offices in Tver and Volgograd, and its representation also in the, so called Novorossiya, at the occupied Ukrainian territory. This agency has organized the Sevastopol Self-defense, of which the Surgeon was part of.

The part of the holding is also The International Center for Special Training Wolf, run by Denis Rjauzov, graduate of the military university, specializing in air and water landing of forces. He holds his special training courses all over the world, in Germany, Switzerland, Serbia, Italy, Hungary and of course in Russia. In addition he trains members of the special forces, police, military, and also the civilians (potentially the mercenaries). He is also a part of the narrow circle of management of the Wolf

\footnotetext{
${ }^{31}$ Nocne Wilki. Pięć powodów, dla których nie możemy wpuścić ich do Polski, strona internetowa: http:/l www.wprost.pl/ar/504277/Nocne-Wilki-Piec-powodow-dla-ktorych-nie-mozemy-wpuscic-ich-doPolski/?pg=0 (dostęp: 9.12.2015).

32 Nocne Wilki szczerza kły także na wschodniej Ukrainie, op. cit.

${ }^{33} \mathrm{http}: / /$ neweasterneurope.eu/articles-and-commentary/1567-night-wolves-putin-s-death-squad
} 
The undisclosed front - aspects of structural pattern and action...

Holding ${ }^{34}$. And when we also consider adding to this large number of domestic and international training centers, where they teach, among the others things, the Russian style fighting technique of the Russian special forces - the Sistiema (instruction centers for this fighting system can be also found in Poland). And the net of possible contacts fills quickly.

Currently in the Ukraine we can observe activities of a nationalistic political party, the Right Sector. The spokeperson of this radical organization, Andrij Tarasenko has said the "it would be just for the city of Przemyśl and more than a dozen of counties to be given to Ukraine". He also added that this "return" should occur through the "diplomatic methods, since we are not an imperialistic nation and we do not ask for foreign lands but what belongs to us" 35 .

The authors consider that the publication of these words may be the modus operandi for diversionary groups. Well, it might be quiet possible for the Russians, ready to antagonize the Poles with Ukrainians, to send its special operations groups (because of the ongoing war in the Eastern Ukraine they have plenty of those) to Poland in the Ukrainian uniforms to perform covert operations. Of course, based on previous activities of such groups we can predict that the very effective Russian diplomacy, as is known, at the same time will be announcing that the Ukrainian Right Sector has begun taking military control of the parts of the NATO and the European Union country. Next they may ask the international community to consider it as a terrorist organization, that they fight with since 2014. This will excuse its own aggression against the Ukraine. And quite possibly may propose to Poland its assistance in fighting those subversion groups to build up its international reputation.

An important aspect of the subversive activities could be an attempt to support, both financially and by providing the personnel and information, the radical organizations and organized criminal groups. The activities of these organizations founded by illegal financial trade could become the foothold of promotinge separatist organization (terrorist) and attempting to destabilize the country. Commencement of such activities can be very straight forward and open, without an implication that any kind of subversive activities are underway. How can it evolve? Usually through the friendly activities of associations or political parties. Such groups are everywhere. For example in Poland there was a political party "Zmiana"36 ("The Change") that sympathized and

${ }^{34}$ Motocykliści czy zabójcy na zlecenie? GPC ujawnia groźne powiązania „Nocnych Wilków”, http://wpolityce.pl/polityka/242080-motocyklisci-czy-zabojcy-na-zlecenie-gpc-ujawnia-groznepowiazania-nocnych-wilkow (7.12.2015)

35 Ibidem, also see: http://niezalezna.pl/65908-niestety-ukraincy-uczcili-upa (dostęp: 1.04.2015).

36 As it is seen in Poland, the pro-Russian party Zmiana (describing itself as the first non-american interests party in Poland) is waiting for the rejestration in the Polish Court. It leader was currently arrested for working on behalf of a foreign entity - the Russia. It can not count even on the small movement, but may promote a political line working against the Polish government. Its leaders are 
openly supported the Russian foreign policy 37 . Whereas, this type of "friendly" organizations can become a potential protagonist for foreign agents ${ }^{38}$ and subversive groups.

There are also the criminal groups that under the influence of foreign state have means to destabilize a country with their criminal activities. The organized crime groups with hierarchical structures always have a network of wide criminal ties developed for activities linked to legal business structures, or even political establishment ${ }^{39}$. This activity might implicate the difficulty in determining the degree of unity amongst the potential saboteurs, since the scope and nature of the participation of individuals in such activity can be only predicted and is seldom known ${ }^{40}$.

In the Ukraine, the use the legally established institutions of all kinds, ranging from educational, social and cultural to humanitarian, sports organizations, which could underline given activities morally and provided wider information support was very broad and common. It is suspected that also the state schools and the paramilitary organizations have been used to stir up anti Ukrainian sentiment among adolescents of the Russian nationality.

The use of legitimate organizations to destabilize another country can be considered the master art of operational intelligence. It should be noted that specific organizations, like the above exemplified the Night Wolves, are an excellent intelligence tool in the hands of the people who are trained to use them for specific purposes in subversive activities. Taking into account the international connections of different associations and status of some of its members, as well as the example of a role they played in the Ukrainian conflict, we can understand that similar activities may be aimed at any country, including especially Poland, and will probably begin with possible activities through the different all kinds of organizations (motorbike association, paramilitaries, security companies, sports associations, rifle associations, minority organizations etc.).

\section{The subversive groups structural analysis}

It is extremely difficult to present universal characteristics of the subversive group structures, or the construction of their doctrinal standards and the organizational

\footnotetext{
not known at large to Polish media and citizens. Source: http://wiadomosci.onet.pl/kraj/zmianapartia-mateusza-piskorskiego-czeka-na-rejestracje/850x2s (14.04.2015).

37 Działacze Zmiany zakłócili program TVP. Proputinowska partia zaczyna swój „dlugi marsz” do polityki?, Source: http://wpolityce.pl/spoleczenstwo/240750-dzialacze-zmiany-zaklocili-programtvp-proputinowska-partia- zaczyna-swoj-dlugi-marsz-do-polityki (dostęp: 14.04.2015).

38 Ile Rosji w Polsce?, http://natemat.pl/139441,prokremlowscy-dzialacze-chca-wyjsc-poza-marginesczy-trolle-putina-stanowia-w-polsce-jakakolwiek-sile (dostęp: 19.01.2016).

39 J.W. Wójcik, Przeciwdziałanie finansowaniu terroryzmu, Warszawa 2007, s. 79-84.

40 W. Jasiński, W. Mądrzejowski, K. Wiciak (red. nauk.), Przestępczość zorganizowana. Fenomen. Współczesne zagrożenia. Zwalczanie. Ujęcie praktyczne, Szczytno 2013, s. 79.
} 
The undisclosed front - aspects of structural pattern and action...

model. This issue is complicated by the fact that a small number of sources containing reliable information useful in the process of analyzing of structures is limiting it flow. The main information on which the focus should be made is data containing the composition, characteristics and quantitative composition of the individual groups, number of cells, ethnic compositions, forms and types of links between other subjects or decision-making elements (the organizational management). The organizational management information is always very hard to obtain, since this type of information implies the full knowledge o both military and political doctrine allowing for the subversion into the foreign territory (of none-agressor) openly against the international law. However, the doctrinal model of the subversive groups may resemble the structures of the special forces units, as observed in the peace time. As the authors believe, this may lead to mistaken identity of such units during a mission or war-time activities. The standardized divisions of special forces in peace time, such as section, group, company, etc. most likely will not be true during a military or subversive activities in real time.

There are a number of reasons for that. One of the most important is the rule of non-schematic actions in order to have a "shadow advantage", so the enemy will not know when, how and sometimes why the attack may occur. As it was described by Victor Suvorov, among the others, the Spetznaz is schooled in simple and elastic structurally actions. The Spetznaz operation implies independent activity under a limited chain of command ${ }^{41}$. At the real time operation these subversive groups can divide itself into several smaller combat sections accordingly or have ability to create bigger tactical groups, dissolving into autonomous sections after the execution of the tasks. For example: on the day of penetration behind the enemy lines, with the 10 subversive groups in day one $-\mathrm{D}+1,3$ of these groups can work together, while the other will operate independently according to individual orders ${ }^{42}$. Then on D+ 2 these groups, after the execution of the first tasks may fall apart into sections and using informants, agents support, elements of organized crime can begin shaping subsequent diversionary groups. Such action create the illusion of a greater operating forces than in reality is the case.

The potential subversion groups' mobility is versatile, while using various types of movements and means of transportation. They can use common transport options like individual or public transport, airline, trains, buses and automobiles, as well as tours operated by tourist bureaus. They can also use the illegal means like clandestine crossing borders using airships, airborne drop, using waves of immigrants, hide among refugees, or migrant workers.

${ }_{41}$ W. Suworow, Specnaz. Historia sit specjalnych Armii Radzieckiej, Warszawa 2002, s. 226.

42 Ibidem. 
Special group can be moved across into action on the eastern and south-eastern Polish territory by land or air. The infiltration of the group by land can be done by most common means. While air transport is the most suitable way for trafficking, because it is uncomplicated, quick and allows movement over a long distance ${ }^{43}$, and in addition by using helicopters it can reduce losses during the landing and can be made with precision even in a wooded area, where the groups can land. Additionally, as the sources indicate, there are some other obvious ways - the humanitarian operations can also be used for subversion groups' movements. This method was mentioned during a testimony of the Spetznas veterans foundation chief, Vladimir Efimov, who admitted that volunteers receive Red Cross false documents showing their affiliation with the humanitarian convoys ${ }^{44}$.

In case of Poland, as the authors claim, the most convenient way of penetration by the special groups into the territory of the Republic of Poland shall be through the Polish-Belarusian border. It is quite long, forested and not very densely populated. From there, these groups will be first moved to the South reaching the Carpathian region, where they can begin to carry out appropriate subversion, diversion and sabotage acts. Of course, there is nothing to prevent the spread of activities into other regions of Poland. It is assessed by the authors that the main organizational scheme of those groups in the enemy territory rests on moving the lower level units to the frontal area of action units, and management of those cells in such a way that its members will not have opportunity to realize how they are organized outside of their own needs, and will not know of the command structures. Hence, the command system rests on orders transmitted orally by "agents connectors" exchanging information with avoidance, especially during the combat operations, of the written orders and reports. This allows coordination of a number of assignments, secret management, and protects against exposure. At the same time in the case of exposure a cell can liquidate any circumstantial evidence what allows to break the grid links to subversion traffic command.

As it was observed in Ukraine, we can make an attempt to characterize those subversive groups. The small groups were abounded. It is estimated that the groups

${ }^{43}$ Materiały do szkolenia taktycznego zwiadowcy i grupy specjalnej, Inspektorat Szkolenia MON, Szkol/455/72, Warszawa 1972, s. 19. See also: http://www.tvn24.pl/wiadomosci-z-kraju,3/nowy-sposobna-przemyt-papierosy-zrzucane-z-motolotni,350054.html (15 IV 2015) plus http://wiadomosci.onet. $\mathrm{pl} /$ swiat/na-motolotni-przemycali-papierosy-Z-ukrainy-do-polski/4vx9ej (15 IV 2015), http://www rp.pl/artykul/1189109.html (15 IV 2015), and http://gazetaolsztynska.pl/204429,Dron-przemycalpapierosy-z-obwodu-kaliningradzkiego.html\#axzz3XOR1X2Mj (15 IV 2015).

Authors believe that the different types of air ships may be used to drop accros the border the armaments and finiancial means for subversive groups, as this is obvious. Those means can be collected in hideouts and can be used at the time of attack.

${ }^{44}$ M. Wojnowski, Koncepcja wojny nowej generacji w ujęciu strategów Sztabu Generalnego Sił Zbrojnych Federacji Rosyjskiej, „Przegląd Bezpieczeństwa Wewnętrznego” nr 13 (17), Warszawa 2015, s. 34. 
The undisclosed front - aspects of structural pattern and action...

operating on the territory of Ukraine and in Donetsk and Lugański districts consisted of about, from 5 to 50 soldiers. Based on that observation and a research leading to analysis of the phenomenon, we can predict an internal relationships among their members. The authors on the basis of the public materials have created a structural model of such a grid.

In assessment of authors' research, a net of subversive groups is determined by: the nature of the affiliation and mutual connections between their members; the degree of organization; and chains of internal connections. The two best examples of subversion organizational structures, always considered at the beginning of an analysis are the following points of the grid ${ }^{45}$ :

- hierarchical (vertical) - creating pyramidal group structure on the principle of straightforward superior - inferior chain of command. Hierarchical arrangement can be helpful in organizing tasks in progress or to protect senior members of the group. This system is more vulnerable to interruption in the case of identification and breakdown on decision-making level;

- net-like (horizontal) consisting of a loose association of members who play individual roles to ensure a success of the whole group. A characteristic feature of this system is lack of functioning dependence and subjugation to the established rules and actual hierarchical connections ${ }^{46}$. A net-like connection may combine within few autonomous hierarchical arrangements. Particular patterns of the SuRG prove, that in some situations this arrangements is more viable than others. The net-like arrangements is optimal for creating dependable bond of trust, especially when the trust must be built at boundaries of legal and none legal activity. This structure also allows for safer conspiracy up keeping. Such patterns can also be regenerated, even if some key member have been identified.

It is a rule that the top command or managerial positions in a subversive group are given to ex officers of the military forces, professional familiar with the basic combat techniques (tactics and fighting) and with knowledge of the basic technical measures of fighting (weapons support, communications) ${ }^{47}$. Based on the research of the activities of subversive groups, as well as that of the organized crime we can present the following types of groups with a specific structural compound ${ }^{48}$ :

45 Ministerstwo Spraw Wewnętrznych i Administracji, Raport o stanie bezpieczeństwa w Polsce w 2008 r., p. 122.

46 M. Cichomski, Struktury zorganizowanych grup przestępczych, [w:] Przestępczość zorganizowana. Fenomen. Wspótczesne zagrożenia. Zwalczanie. Ujęcie praktyczne, red. W. Jasiński, W. Mądrzejewski, K. Wiciak, Szczytno 2013, p. 69.

47 Strzelanina SBU z rosyjskimi agentami w Kijowie, http://kresy24.pl/75894/strzelanina-sbu-zrosyjskimi-agentami-w-kijowie-sa-zabici-wideofoto/ (dostęp: 14.12.2015).

${ }^{48}$ M. Cichomski, A. Fraj-Milczarska, Struktura zorganizowanych grup przestępczych, [w:] Praktyczne elementy zwalczania przestępczości zorganizowanej i terroryzmu. Nowoczesne technologie i praca operacyjna, L. Paprzycki. Z. Rau, edits, Warszawa 2009, s. 197. 
- standard - the simplest form of organization of the SuRG, with one leader and clearly defined roles of the subordinates. A characteristic feature of this pattern is harsh discipline and a strong sense of identity, often based on intragroup relationship and ethnic origin;

- cluster - pattern characterized by a collective form of management. In it, there is a few leaders with similar or equal powers, who jointly make decisions on the activities of the group at the tactical level;

- core - in this SuRG one can identify the existence of a certain number of closely cooperating members, who, depending on the current needs take periodic cooperation with loosely associated additional members, who perform, if necessary, specific services for the SuRG;

- spider - this type of group is based on the activities of several key figures, unidentified directly with the group membership, but forming a network of links connecting the various subversive projects. The structure of links can also be connected to unidentified members within other groups, each of which has a different built up. In such a case not all the links have the same value and network of links is a variation of those of a leader(s) and different surrounding connections.

The vocation of the group and its nature and multiplicity are the key factors affecting the type of their structural pattern. It is anticipated that the group discipline would be maintained through some radical means, oath for the members, stimulation of ambition and hatred. A system of strict penalties (including death penalty) can also be mainteind.

\section{Subversive Reconnaissance Groups and connections with the orga- nized crime}

Elements of the Polish organized crime groups are not isolated from other types of criminal structures and activities within an international setting, or operating in the territory of another state. We can observe different evolutions of this criminal activity, and one of them is the internal restructuring of some hooligan groups' organizational schemes and its internal and external hierarchy, of which some are growing in the direction of organized criminal groups but others already operate as such an entity. Its background is usually soccer clubs supporter sphere and associated football fans, etc. Criminal groups use the "stadion hooligans" with knowledge of the local environment and engage them in drug trafficking or in other various activities.

The exact knowledge of an environment and locations is an excellent source of informational support for the potential saboteurs. The use of criminal structures in the process of implementation of the subversion allows a deep penetration of local environments in almost every aspect. The criminal environment can support agents 
The undisclosed front - aspects of structural pattern and action...

and subversive reconnaissance groups in their tasks. The underworld can also be used for the smuggling of arms and people, to control behavior of the local community, as well as the human resources sphere to support such activities as direct targeting and attacking, for fighting or other activity of subversive or terroristic kind.

An important aspect of such activities of the organized crime is its impact on the extremist's environment. It should be noted that during the research on the Polish criminal environment there were spotted some single conviction cases of the representatives from radical circles, building or participating in an organized criminal group ${ }^{49}$.

When considering the impact of organized crime on the possibility of supporting possible subversion, one should mention about on of the Russian mafia groups: Soloncew ${ }^{50}$, which at end of the twentieth century, late nineties, had approximately 7000 troops, recruited from Specnaz and the KGB ${ }^{51}$. Such connections create a web of links that can be used in achieving the objectives of a potential saboteur. Using the principle of support, as a mentor he can operationally control the activities of such a group in various aspects. After the execution of the tasks, the criminal group or its individual member, can be physically eliminated behind a screen of gang violence with a competition, or law enforcement's activity issuing the arrest warrant as a result of indications of informants.

\section{Technical and material resources and funding for the SuRGs}

Presumably the SuRG's technical resources will include stocks of melee weapons, plus short and long firearms. This will include those weapons and explosives hidden by the population during the World War II, and collected as a historical value by various collectors and paramilitary organizations, as well as guns purchased legally in stores. Probably an additional assistance will come with the weapons smuggled from different regions of Europe (mainly from the internal conflict-stricken Ukraine).

The funds will come from a variety of sources. For example, during the war in Ukraine saboteurs were supported financially by various foundations. It is estimated that the average monthly salary oscillates in the range of 60 to 90 thousand rubles for the services of diversionary groups members. Probably the command level compensation

49 Ministerstwo Spraw Wewnętrznych i Administracji, Raport o stanie bezpieczeństwa w Polsce w 2010 r., Warszawa 2011, s. 287.

50 At the turn of 1980s and 90s, when mafia in Poland was evolving, Sołoncewo was already a stronghold as a crimingal holding. In the raport of the Federal Bureau of Investigation (the FBI) of 1995, about the international criminal groups, the Solncewo mafia was considered to be the biggest Eurasian criminal organization in a world, with its financial gains and potential of control. Source: http:// www.polityka.pl/tygodnikpolityka/kraj/287731,1,mafiosi-demoludow.read, http://www.wprost.pl/ ar/53363/Pruszkow-pod-Moskwa/ (dostęp: 11.02.2016).

51 W. Sumliński, Czego nie powie Masa o polskiej mafii, Warszawa 2015, s. 106. 
is much higher. An additional financial resources these groups collect from criminal activities in the areas of field operation. Supervision and cooperation with organized crime will allow enlistment of additional income for operational activities.

According to the information from the Revenue Inspector General Office, every year in a money laundering process approximately 9 billion dollars enters economy from the criminal activity. Officers of the Central Bureau of Investigation estimate that almost $\$ 5$ billion of this sum is laundered in Poland by Solncewo ${ }^{52}$. Parts of the acquired sums can provide the operational fund, spent as needed, subversive groups.

This type of activity would be done in addition to operations of special forces in individual clandestine proceedings, using appropriate tactics. At the time of the special operations the group will be in constant motion, what implies taking only the minimal amount of equipment, while considering the transport capabilities. Sometimes the group may receive its supplies by air.

Considering the possible traits of such actions, one of its symptoms within the area of operation by subversive groups may be the loss of food products or live stock from farms, theft from shops located in rural areas, or others. There is also the likelihood that members of these groups wearing civilian cloths will be make legitimate purchases in shops. In the border regions of Northern, Northeastern and Eastern Poland foreigners who speak only Russian or broken Polish are not unusual enough to raise any suspicions.

\section{Conclusion}

Summing up the above considerations, it should be pointed out that it is very important for the people who hold public administration posts, related to national security, to be aware of the potential activities that may take place in any country, including Poland. One should not reject the possibility that on the Polish territory there will be secretly operating foreign soldiers, performing subversive actions. The fact that we are a member state of the EU and NATO will not protect us against the movements of hostiles within Polish border. The only real protection will be based on suitable attitude of state and local government authorities providing the appropriate equipment and training of the services responsible for public safety.

In the opinion of the authors, the implication of conflict in Ukraine is only the first stage of the strategy that is extended in time. The process of destabilizing this region of Europe can last for years. This is confirmed by recent press reports concerning the fact that Latvian Russians asked in their homeland capital, abroad in Moscow, to intervene on their account ${ }^{53}$.

\footnotetext{
52 http://www.wprost.pl/ar/53363/Pruszkow-pod-Moskwa/ (dostęp: 11.02.2016).

$53 \mathrm{http}: / /$ wpolityce.pl/swiat/238975-zaczyna-sie-lotewscy-rosjanie-poprosili-swoja-zagranicznaojczyzne-o-interwencje-na-razie-polityczna (dostęp: 8.04.2015).
} 
The undisclosed front - aspects of structural pattern and action...

At the same time, Russia may try to antagonize Poland with its north-eastern neighbor - Lithuania. In such a case they can use a method used since the days of the Imperial Tsarist Russia, to antagonize Poles living in Vilnius and areas adjacent to the city with the other citizens of Lithuania. To do this they may try to influence or control the structures of The Electoral Action of Poles in Lithuania. This political party may be unaware of the infiltration and may start cooperating with the Russians, who will use any means possible to reach and target any political or military goal ${ }^{54}$.

A large autonomy and clandestine characteristics of the subversive activities rely on employment of appropriate and very specific methods of operation. This makes the operations of these groups fall as an indirect activity in-between military special operations and those of the intelligence services, and as such should be fought. Only cooperation between the unitary and non-unitary levels of public administration and Polish Military Forces will allow the proper and efficient identification of the subversive groups and allow for neutralization of such groups, both in times of peace and war.

\section{BIBLIOGRAPHY}

1. Cichomsкi M., Struktury zorganizowanych grup przestępczych, [w:] Przestępczość zorganizowana. Fenomen. Współczesne zagrożenia. Zwalczanie. Ujęcie praktyczne, red. W. Jasiński, W. Mądrzejewski, K. Wiciak, Szczytno 2013.

2. Cichomski M., Fraj-Milczarska A., Struktura zorganizowanych grup przestępczych, [w:] Praktyczne elementy zwalczania przestępczości zorganizowanej i terroryzmu. Nowoczesne technologie i praca operacyjna, red. L. Paprzycki. Z. Rau, Warszawa 2009, s. 197.

3. Doktryna Operacje specjalne DD/3.5, Dowództwo Wojsk Specjalnych, DWSpec. 1/2011, Kraków 2011.

4. Działania specjalne, Sygn. Szt. Gen. 1221/85, Warszawa 1985.

5. JAsiŃski W., MĄDRZejowski W., Wiciak K. (red. nauk.), Przestępczość zorganizowana. Fenomen. Wspótczesne zagrożenia. Zwalczanie. Ujęcie praktyczne, Szczytno 2013.

6. Kautilya, Arthashastra, http://www.lib.cmb.ac.lk/wp-content/ uploads/2014/01/ Arthashastra_of_Chanakya _-_English.pdf

7. Lahneman W.J., The Need for a New Intelligence Paradigm, "International Journal of Intelligence and CounterIntelligence" (2010), http://dx.doi.org/10.1080/08850600903565589

8. LewCZaK T., ATO nie wojna, „PARABELLUM Niezależny Magazyn Strategiczny” nr 3/2015.

9. Materiały do szkolenia taktycznego zwiadowcy i grupy specjalnej, Inspektorat Szkolenia MON, Szkol./455/72, Warszawa 1972.

\footnotetext{
${ }^{54} \mathrm{http} / / /$ www.defence24.pl/analiza_moskwa-przygotowuje-konflikt-hybrydowy-z-wilnem-wykorzystalitewskich-polakow (dostęp: 8.04.2015).
} 
10. NATO Glossary of Terms and Definition, AAP-6(2005), http://docplayer.pl/2373154-Nato-pfp-unclassified-aap-6-2005-nato-pdp-jawne-aap-6-slownik-terminow-i-definicjinato-nato-glossary-of-terms-and-definitions.html

11. PAwLIKowicz L., Aparat centralny 1. Zarządu Głównego KGB jako instrument realizacji globalnej polityki Kremla 1954-1991, Oficyna Wydawnicza RYTM, Warszawa 2013.

12. Raport o stanie bezpieczeństwa w Polsce w 2008 r., Ministerstwo Spraw Wewnętrznych i Administracji, Warszawa 2008, https://bip.mswia.gov.pl/bip/raport-o-staniebezpie/18405,Raport-o-stanie-bezpieczenstwa.html

13. Raport o stanie bezpieczeństwa w Polsce w 2010 r., Ministerstwo Spraw Wewnętrznych i Administracji, Warszawa 2011, https://bip.mswia.gov.pl/bip/raport-o-staniebezpie/18405,Raport-o-stanie-bezpieczenstwa.html

14. Rosenau W., Subversion and Insurgency, Rand Counterinsurgency Study, Paper 2, Occasional Paper, Prepared for the Office of the Secretary of Defense, http://www.rand. org/content/dam/rand/pubs/occasional_papers/2007/RAND_OP172.pdf

15. Sumliński W., Czego nie powie Masa o polskiej mafii, Warszawa 2015.

16. Suworow W., Specnaz. Historia sił specjalnych Armii Radzieckiej, Warszawa 2002.

17. Tzu S., Sztuka wojny. Traktaty, Gliwice 2004.

18. Wojnowski M., Koncepcja wojny nowej generacji w ujęciu strategów Sztabu Generalnego Sił Zbrojnych Federacji Rosyjskiej, „Przegląd Bezpieczeństwa Wewnętrznego” nr 13 (17), Warszawa 2015.

19. Wóscıк J.W., Przeciwdziałanie finansowaniu terroryzmu, Warszawa 2007.

\section{ARTYKUŁY INTERNETOWE:}

1. Analiza: Moskwa przygotowuje konflikt hybrydyowy z Wilnem - wykorzysta litewskich Polaków, http://www.defence24.pl/analiza_moskwa-przygotowuje-konflikt-hybrydowyz-wilnem-wykorzysta-litewskich-polakow (dostęp: 8.04.2015).

2. Były oficer FSB ujawnia. „Rosja zaangażowana $w$ rozruchy $w$ Londynie, ataki $w$ Paryżu, ISIS", http://niezalezna.pl/73671-byly-oficer-fsb-ujawnia-rosja-zaangazowana-wrozruchy-w-londynie-ataki-w-paryzu-isis.

3. Dron przemycal papierosy z obwodu kaliningradziego, http://gazetaolsztynska. pl/204429,Dron-przemycal-papierosy-z-obwodu-kaliningradzkiego.html\#axzz3XOR1X2Mj (dostęp: 15.04.2015).

4. Działacze Zmiany zakłócili program TVP. Proputinowska partia zaczyna swój „długi marsz" do polityki?, http://wpolityce.pl/spoleczenstwo/240750-dzialacze-zmianyzaklocili-program-tvp-proputinowska-partia- zaczyna-swoj-dlugi-marsz-do-polityki, (dostęp: 14.04.2015).

5. Hybrydowa wojna - hybrydowa reakcja, http://www.nato.int/docu/review/2014/Russia-Ukraine-Nato-crisis/Russia-Ukraine-crisis-war/PL/index.htm (dostęp: 29.12.2015).

6. Ile Rosji w Polsce?, http://natemat.pl/139441,prokremlowscy-dzialacze-chca-wyjsc-pozamargines-czy-trolle-putina-stanowia-w-polsce-jakakolwiek-sile (dostęp: 19.01.2016). 
The undisclosed front - aspects of structural pattern and action...

7. Jak rosyjski specnazowiec-neonazista Krym od faszystów wyzwolit, http://kresy24. pl/69245/jak-rosyjski-specnazowiec-neonazista-krym-od-faszystow-wyzwolil-wideofoto/ (dostęp: 9.12.2015).

8. Łotewski Polak rosyjskich „Wilków” Putina, http://kresy24.pl/67504/lotewski-polak-rosyjskich-wilkow-putina/ (dostęp: 7.12.2015).

9. Mafiosi domoludów, http://www.polityka.pl/tygodnikpolityka/kraj/287731,1,mafiosi-demoludow.read,

10. Motocykliści czy zabójcy na zlecenie? GPC ujawnia groźne powiązania „Nocnych Wilków”, http://wpolityce.pl/polityka/242080-motocyklisci-czy-zabojcy-na-zlecenie-gpcujawnia-grozne-powiazania-nocnych-wilkow (dostęp: 7.12.2015).

11. Na motolotni przemycali papierosy z Ukrainy do Polski, http://wiadomosci.onet.pl/swiat/ na-motolotni-przemycali-papierosy-z-ukrainy-do-polski/4vx9ej (dostęp: 15.04.2015), http://www.rp.pl/artykul/1189109.html (dostęp: 15.04.2015).

12. Na Ukrainie schwytali terrorystę $z$ ISIS!, http://kresy24.pl/75360/na-ukrainie-schwytaliterroryste-z-isis-byl-uzbrojony-po-zeby-foto/ (dostęp: 14.12.2015).

13. Niestety Ukraińcy uczcili UPA, http://niezalezna.pl/65908-niestety-ukraincy-uczcili-upa, (dostęp: 1.04.2015).

14. Night Wolves - Putin's Death Squad, http://neweasterneurope.eu/articles-andcommentary/1567-night-wolves-putin-s-death-squad

15. Nocne Wilki szczerzq kły także na wschodniej Ukrainie, http://www.tvp.info/19792456/ nocne-wilki-szczerza-kly-takze-na-wschodniej-ukrainie (dostęp: 09.12.2015r.).

16. Nocne Wilki. Pięć powodów, dla których nie możemy wpuścić ich do Polski, http://www. wprost.pl/ar/504277/Nocne-Wilki-Piec-powodow-dla-ktorych-nie-mozemy-wpuscicich-do-Polski/?pg=0 (dostęp: 9.12.2015).

17. Nowy sposób na przemyt - papierosy zrzucane z motolotni, http://www.tvn24.pl/wiadomosci-z-kraju,3/nowy-sposob-na-przemyt-papierosy-zrzucane-z-motolotni,350054. html (dostęp: 15.04.2015).

18. Pruszków pod Moskwą, http://www.wprost.pl/ar/53363/Pruszkow-pod-Moskwa/ (dostęp: 11.02.2016).

19. Strzelanina SBU z rosyjskimi agentami $w$ Kijowie, http://kresy24.pl/75894/strzelaninasbu-z-rosyjskimi-agentami-w-kijowie-sa-zabici-wideofoto/ (dostęp: 14.12.2015).

20. Zaczyna się - łotewscy Rosjanie poprosili swoją zagraniczna ojczyznę o interwencję, na razie polityczna, http://wpolityce.pl/swiat/238975-zaczyna-sie-lotewscy-rosjaniepoprosili-swoja-zagraniczna-ojczyzne-o-interwencje-na-razie-polityczna (dostęp: 8.04.2015).

21. Zmiana - partia Mateusza Piskorskiego czeka na rejestrację, http://wiadomosci.onet. $\mathrm{pl} / \mathrm{kraj} / \mathrm{zmiana}$-partia-mateusza-piskorskiego-czeka-na-rejestracje/850x2s (dostęp: 14.04.2015). 


\section{NA TAJNYM FRONCIE. WZORZEC STRUKTURALNY I DZIAŁANIA SIA- TEK DYWERSYJNO-ROZPOZNAWCZYCH W NOWOCZESYM KONFLIKCIE ZBROJNYM. ANALIZA ASPEKTÓW W OPARCIU O ŹRÓDŁA OGÓLNODO- STĘPNE}

Streszczenie. Tematy rozważane w obszarze działań formacji wywiadowczych można odnieść do różnorodnych sfer bezpieczeństwa państwa i jego interesów. W przypadku strategii bezpieczeństwa informacje uzyskane ze źródeł otwartych i innych są niezwykle ważne, czasami żywotne, a innymi razem instrumentalne w zabezpieczeniach państwowej suwerenności. Oczywiście, informacje związane z działaniami dywersyjno-rozpoznawczymi agresora są niezwykle trudne do uzyskania, tu jednak źródła otwarte mogą być pomocne przy ich analizie wskazującej na agendę agresora i możliwy zasięg i możliwości zagranicznego wywiadu w destabilizacji kraju lub całego regionu. Obecnie przykładem takiej aktywności jest rosyjskie zaangażowanie w wojnie we wschodniej Ukrainie oraz aneksja Półwyspu Krymskiego. Analizując informacje odnoszące się do działań rosyjskich na Ukrainie i w jej sąsiednich państwach, w tym zwłaszcza w Polsce, można zaobserwować wzorce określające sposoby prób kontroli ważnych aspektów bezpieczeństwa państwa. Autorzy tego artykułu analizują na podstawie źródeł otwartych dostępne informacje związane z działaniem wywiadów w zakresie dywersyjno-rozpoznawczym, zmierzającym do podważenia wiarygodności państwa i jego działań. Przykładowo pokazana jest sytuacja na Ukrainie z próbą zawładnięcia jej przestrzeni przez wywiad rosyjski. Przekłada się to również na aspekty dotyczące Polski i innych krajów oraz próby kontroli sfer suwerenności.

Słowa kluczowe: wywiad, kontrwywiad, tajne operacje, jawne operacje, dywersja, polityka. 